\title{
乱流境界層内に設置されたビル模型後方の物質拡散過程 \\ Mass Diffusion Process behind a Building Model in Turbulent Boundary Layer
}

\author{
渡邊 拓也 (名工大院) 正 保浦 知也 (名工大) \\ 正田川 正人(名工大)
}

Takuya Watanabe, Tomoya Houra and Masato Tagawa

Nagoya Institute of Technology, Gokiso-cho, Showa-ku, Nagoya 466-8555

\begin{abstract}
Recently, various detrimental substances exhausted from a large number of cars and/or factories have been making a large influence on living environments in the large urban area. Thus, it is necessary to predict accurately the diffusion processes of such substances in the city area, which has a very complex flow field because of the existence of various buildings in size and shape. To tackle this problem, we need simplify the flow field to find the relations between mass diffusion and the flow behind a building model. In the present study, we investigate experimentally the fluid-dynamical relationship between mean velocity and concentration fields formed behind the building model by focusing attention on the behaviors of the streamwise mass flux and turbulence intensity.
\end{abstract}

Key Words : Turbulent Boundary Layer, Building Model, Mass Diffusion, Mass Flux

\section{1. 緒言}

近年の都市部では，自動車や工場などが排出する有害物質 による環境問題が取り挙げられ，その拡散過程の予測や都市計 画への提害が求められている。大気污染を流体力学的な立場 から考えるとき，都市を構成する建築物の存在がそれに及ぼす 影響は大きい，そのため，建築物によって変化する速度場と物 質の移流拡散過程との関係を調べることは非常に重要である。

建物近傍の物質拡散については，物質が建物上面 (屋根面) (1)(2) や上流の一点 ${ }^{(3)}$ から排出される場合の建物後方の濃度分 布特性が調べられている，とりわけ，物質を点源供給する場合 には，供給口と建物との位置関係によって拡散過程が多様に 変化すると考えられるので，さらなる調査が必要である，建 物に衝笑する流机は上壁や側壁の存在によって大きく曲げら れる。例えば，ビル模型側面において上方から下方へ吹き下 がる流れがあることが知られている。このような特徵的な速 度場が，上流から供給された物質の搪散過程に及ぼす影響は 非常に興味樑い.

本研究では, 乱流境㽞層内に単一のビル模型を設置し, 物質 が上流から点源供給された場合に観察されるビル模型後方の 物質拡散過程を実験的に調べてその発現機構を明らかにする。

\section{2. 実験装䈯および方法}

風洞 (4) (5) は吸込み式の低乱風洞であり，コントラクショ ン比 $4: 1$, 測定部断面積 $0.5 \times 0.5 \mathrm{~m}^{2}$, 長さ $4 \mathrm{~m}$ である. 乱流 境界層を安定に発達させるために, 測定部入口にトリッピン グプレートを設けた。測定部入口から $X=2250 \mathrm{~mm}$ の位置 にビル模型 $(D \times D \times H=20 \times 20 \times 50 \mathrm{~mm})$ を設㯰し，この 中心位置を $x=0 \mathrm{~mm}$ とする。ビル模型は主流に対して角度 $\theta=0^{\circ}, 45^{\circ}$ で設䈯した。ビル模型周りの速度場はPIV (粒子 画像流速測定法)によって計測した。物質には空気と分子舅が ほぼ等しくシュミット数が 1 に近いエチレンを用いて，その時 間平均濃度をガスクロマトグラフ (島津製作所製 GC2014)に より測定した。エチレンは $X=1950 \mathrm{~mm}(x=-300 \mathrm{~mm})$ の 位置で図1のように点源供給される。供給口は真鍮製のパイ プで内径 $1 \mathrm{~mm}$, 外径 $1.4 \mathrm{~mm}$ である. 供給高さは $y_{\mathrm{s}}=15,25$ , $35 \mathrm{~mm}$, 供給速度 $U_{\mathrm{s}}=5 \mathrm{~m} / \mathrm{s}(Q=0.235 \mathrm{l} / \mathrm{min})$ とした，エチ レン襄度分布は, 口径 $50 \mu \mathrm{m}$ のガスサンプリングプローブを 模型後方 $x=20,40,60 \mathrm{~mm}$ の位置で $y, z$ 方向にトラバースし て湘定される。
本実験では，主流速度を $\bar{U}_{0}=8 \mathrm{~m} / \mathrm{s}$ に設定した。このとき， 模型設置位置 $X=2250 \mathrm{~mm}(x=0 \mathrm{~mm})$ での速度境界層厚さ は $\delta=44 \mathrm{~mm}$ であった．なお，模型の幅 $D$ に基づくレイノル ズ数は $R e_{D}=\bar{U}_{0} D / \nu=11000$, 運動量厚さに基づくレイノ ルズ数は $R_{\theta}=2800$ であった。

\section{3. 実験結果および考察}

3.1 ビル模型後方の平均濃度場の特性

図 2 は角度 $\theta=0^{\circ}, 45^{\circ}$, 供給高さ $y_{\mathrm{s}}=25 \mathrm{~mm}$ の場合の $x=20 \mathrm{~mm}$ における平均濃度分布 $\bar{C}[\mathrm{ppm}]$ をビル模型の下流 側から兒た結果である。図 2 から，上流から供給された物質は ビル模型に衝笑したのち，その側面や上面を回り込みながら模 型後方へと翰送されていくことがわかる。平均濃度場のピー ク位置は, 供給口高さ $y_{\mathrm{s}}=15 \mathrm{~mm}$ および $y_{\mathrm{s}}=25 \mathrm{~mm}$ の場合 にはそれぞれ $y=5 \mathrm{~mm}, y=20 \mathrm{~mm}$ となり, 供給口の高さよ りも低くなる。一方， $y_{\mathrm{s}}=35 \mathrm{~mm}$ ではピーク位置が $y=35$ $\mathrm{mm}$ となってピーク位置の低下は見られない。この原因は， PIV による速度埸の測定結果によれば，模型側面の $y<35 \mathrm{~mm}$ $(y / H<0.7)$ の領域に存在する吹き下がり流れ $(\bar{V}<0 \mathrm{~m} / \mathrm{s})$ が 物質輸送過程を支配しているためと考えられる。また，図 2 か らわかるようにスパン方向の分布はいずれの設置角, 供給口 高さについても模型側面から $5 \mathrm{~mm}$ 程度離れた位置に濃度の ピークをもつ

そこで, 物質の拡散過程において, その濃度のピーク位置 の挙動とビル模型後方の速度場の関係を明らかにするために，

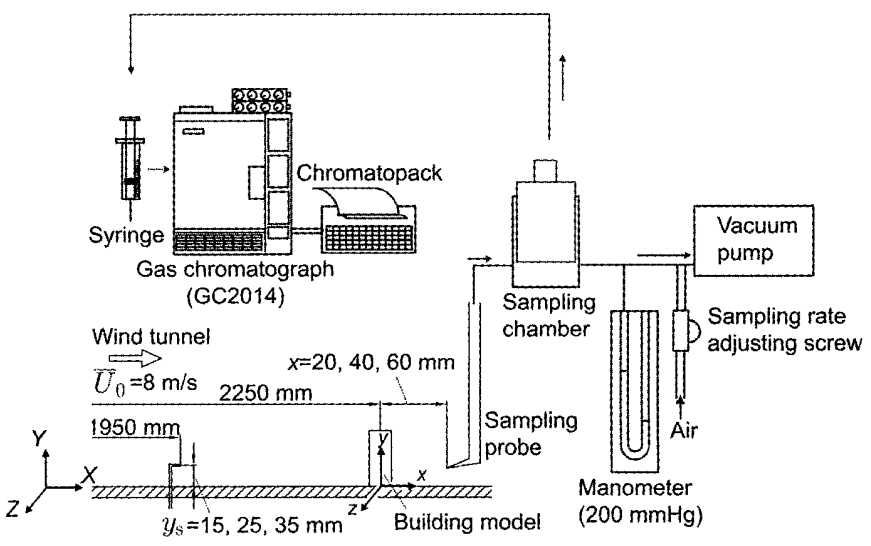

Fig. 1 Experimental apparatus and measurement system 


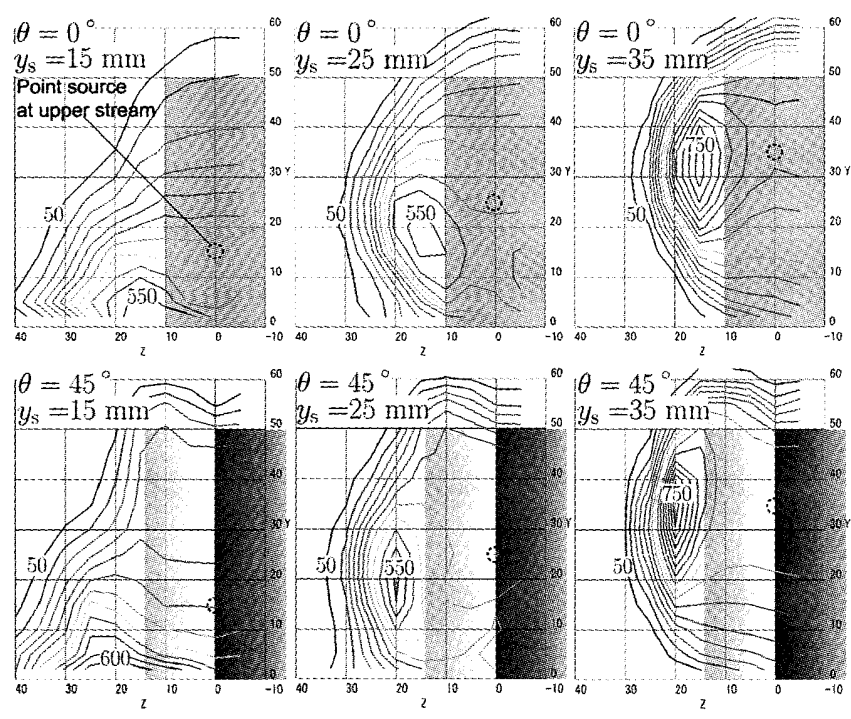

Fig. 2 Mean concentration distribution $\bar{C}$ behind a building model $(x=20 \mathrm{~mm})$

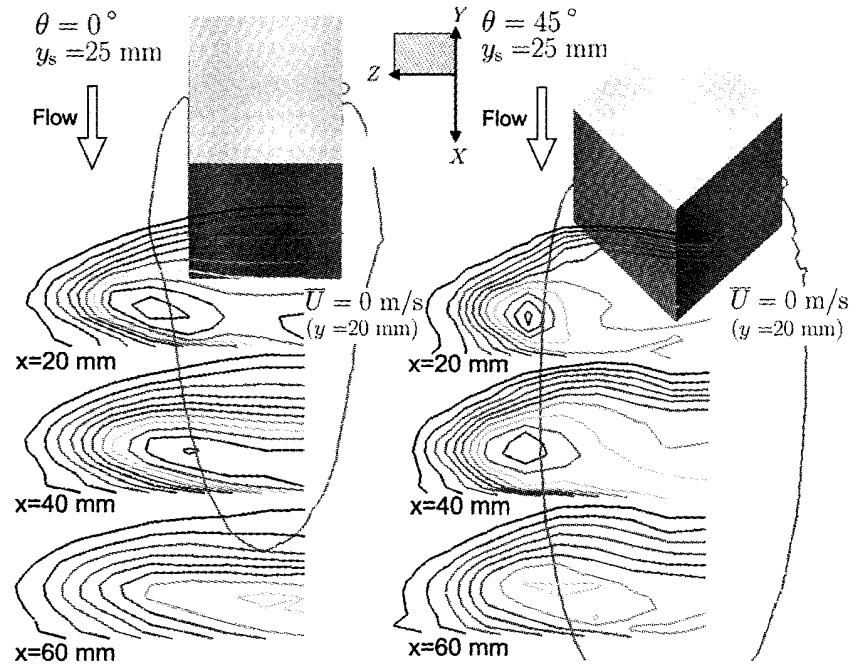

Fig. 3 Positional relationship between mean concentration distribution $\vec{C}$ and $\vec{U}=0 \mathrm{~m} / \mathrm{s}$ behind a building model

濃度場が下流方向に発達する様子を調べた。結果を図 3 に亦 す。図 3 では, 主流方向の 3 点 $x=20,40,60 \mathrm{~mm}$ における 平均濃度分布 $\bar{C}$ を, $y=20 \mathrm{~mm}$ で流机方向平均速度が $\bar{U}=0$ $\mathrm{m} / \mathrm{s}$ となる位置と併せて亦した。これによると，物䓄濃度は流 れ方向平均速度 $\bar{U}=0 \mathrm{~m} / \mathrm{s}$ 付近でピークとなって下流へと拡 散していくことが明らかになった。

\section{2 ビル模型後方における流れ方向物質流束の挙動}

本節では，物犋が流れ方向平均速度 $\bar{U}$ で濃度測定面 $(y-z$ 平面)に流入する場合の物質流束を $\bar{U} \bar{C}$ で評価してその特性 を明らかにする.図 4 に $\theta=0^{\circ}, 45^{\circ}$ ，供給口高さ $y_{\mathrm{s}}=25 \mathrm{~mm}$ の場合の $x=20 \mathrm{~mm}$ における流れ方向物質流束 $\bar{U} \bar{C}$ の分布を 示す. 図4では, 物質流束 $\bar{U} \bar{C}$ と平均濃度 $\bar{C}$ の分布を, それ ぞれ奉線と破線で示す。図4からわかるように, 両者のピー ク位置の高さは変化しないが, スパン方向については物質流 束 $\bar{U} \bar{C}$ は平均濃度 $\bar{C}$ に対して $5 \mathrm{~mm}$ 程度外側にシフトする. そこで, 物質がビル模型後方へと拡散していく過程において, 速度場が物質流束 $\bar{U} \bar{C}$ のピーク位置に及ぼす影響を調べた。 結果の一例を図 5 に亦す。ここでは, ビル模型後方 $x=20,40$ ，60 mmにおける物質流束 $\bar{U} \bar{C}$ の分布と $y=20 \mathrm{~mm}$ において 流れ方向速度乱れ強さが大きい領域 $\left(u_{\mathrm{rms}} / \widetilde{U}_{0}=0.2 \sim 0.3\right)$ を 同時に示している。図 5 から, 物筫流束 $\widetilde{U} \vec{C}$ は速度乱れ強さ
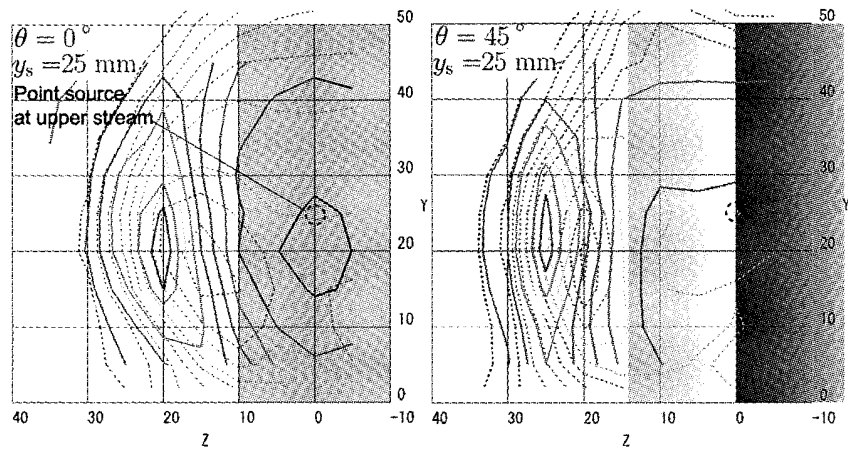

Fig. 4 Comparison between streamwise mean mass flux distribution $\bar{U} \bar{C}$ (solid lines) and mean concentration distribution $\bar{C}$ (dashed lines) behind a building model $(x=20 \mathrm{~mm})$
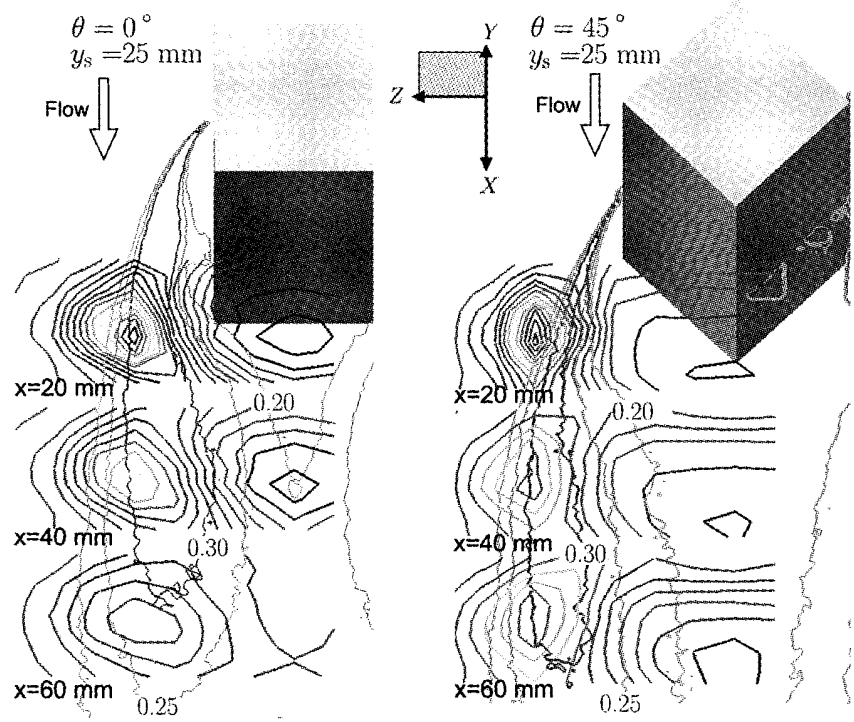

Fig. 5 Positional relationship between streamwise mean mass flux distribution $\widetilde{U} \overleftrightarrow{C}$ and $u_{\mathrm{rms}} / \widetilde{U}_{0}=0.2 \sim 0.3(y=20 \mathrm{~mm})$ behind a building model

が最大となる付近でピークをとりながら下流へと広がってい くことがわかる。

\section{4. 結 言}

作動流体を空笑とする乱流境䍜㬝内にビル模型を設置し， 上流から点源供給された物筫 (エチレン)が模型後方へ移流拡 散ずる過程を実験的に調べた。結果は以下のとおりである。

(1) ビル模型側面の $y<35 \mathrm{~mm}(y / H<0.7)$ の領域に壁面方 向に吹き下がる特徽的な流れが存在する。この流れに支 配されて, 供給口高さ $y_{\mathrm{s}}=15,25 \mathrm{~mm}$ の場合には平均濃

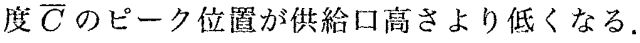

（2）ビル模型後方の平均濃度場 $\bar{C}$ は, 流れ方向速度 $\bar{U}=0$ $\mathrm{m} / \mathrm{s}$ 付近でピークとなって下流へ挔散していく.

(3) 流れ力向物質流束 $\bar{U} \bar{C}$ は，ビル模型後方の速度乱れ強さ が最大となる付近にピークをもつ。

謝辞 本破究の…部は, 財団法人日東学術振興財団の助成に よる。ここに記して謝意を表する。

文献

（1）西村浩一ら他 2 名, 大気摆境学会誌 34-2 (1999), 103-122

（2）老川進ら他 4 名, 大気環境学会誌 34-2 (1999), 123-136

（3）田村哲郎弓他 2 名, 大気環境学会誌 40-2 (2005), 51-66.

(4) Houra, T. and Nagano, Y., Flow, Turbulence and Combustion, 83 (2009), 389-406.

(5) Houra, T. et al., Turbulence, Heat and Mass Transfer 6 (2009), 857 . 860. 